\begin{tabular}{cccc} 
Available online at www.sinjas.journals.ekb.eg & $\overline{\text { PRU-EGYPT }}$ \\
\hline SCREenED BY SINAI Journal of Applied Sciences
\end{tabular}

\title{
BEEF BURGER QUALITY CHARACTERISTICS AND SHELF LIFE IMPROVEMENT BY MARJORAM ADDITION
}

\author{
Menna M.I. Ragab, S.H. Mosilhey, M.A.S. Abdel-Samie* and S.S. Gad
}

Food and Dairy Sci. and Technol. Dept., Fac. Environ. Agric. Sci., Arish Univ., Egypt.

\begin{tabular}{l} 
ARTICLE INFO \\
\hline Article history: \\
Received: $01 / 08 / 2020$ \\
Revised: $10 / 08 / 2020$ \\
Accepted: $12 / 08 / 2020$ \\
Available online: $12 / 08 / 2020$ \\
\hline Keywords: \\
Marjoram, \\
Beef Burger, \\
natural alternative \\
preservatives.
\end{tabular}

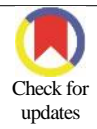

\begin{abstract}
Marjoram was applied to beef burger to improve its physical and chemical properties and to extend its shelf life. Marjoram was added to beef burger in two forms; ethanolic extract at $0.1,0.2$ and $0.3 \mathrm{~g} / 100 \mathrm{~g}$ and as dry powder at $0.2,0.4$ and $0.6 \mathrm{~g} / 100 \mathrm{~g}$ and was stored at freezer $\left(-18^{\circ} \mathrm{C}\right)$ for three months. Chemical properties including moisture, protein, fat contents and $\mathrm{pH}$ values, physical properties (water holding capacity), cooking characteristics (shrinkage, cooking loss and cooking yield), shelf life limiting parameters (TBA, TVN and total plate count) and sensory evaluation test were all investigated. Moisture, protein and water holding capacity increased in both additives (marjoram extract and marjoram powder) added to the burger recipe and these parameters decreased at the end of storage period while fat increased with additives and after storage. All cooking parameters improved as shrinkage and cooking loss decreased with marjoram addition while cooking yield increased. TBA, TVN and total plate count at all added marjoram samples were lower than control at zero time and increased through time in all samples but marjoram added beef burger samples showed less increase rate comparing to that of control. Sensory evaluation test showed that marjoram ethanolic extract and powder did not alter sensory parameters make marjoram a potential application in beef burger.
\end{abstract}

\section{INTRODUCTION}

Food suffers a loss reaches one-third of the total, the loss happens especially during transport and storage because of microbial and chemical reactions including moisture changes and oxidation Fao (2011). Toxicity and many diseases and illnesses might be a consequence of food spoilage, that might first affect the quality parameters, sensory characteristics and nutritional value (Gómez-Aldapa et al., 2014; Hannon et al., 2017). Microbial contamination may infect food via slaughtering, processing, packaging and shipping while lipid oxidation occurs through the exposure of food to atmospheric oxygen (Tian et al., 2013).

Meat and processed meats show an importance for their benefits for human health as it is the only source of essential amino acids and many other nutrients. Of meat products, beef burger possess a special importance for a wide segment of consumers in their daily food habits for being nutritious, cheap, with various types and flavors and being ready to eat with minor preparation processing (Mohamed et al., 2011). Meat industry and its products have possessed a focus because meat is easy contaminated which lead to spoilage and chemical changes cause quality deterioration (Chinprahast $\boldsymbol{e t}$ al., 2012). Of chemical changes that possess a great part of quality deterioration, lipid oxidation is the most important. It causes off-flavor causing shelf-life shortening and sensory parameters deterioration (Gandemer, 2002). Furthermore, many toxic compounds that affect health including circulatory system hazards, cancer and aging is an accompanying food oxidation that cause rancidity (Dos Santos Silva et al.,

\footnotetext{
* Corresponding author: E-mail address: mampowerd@ hotmail.com https://doi.org/10.21608/SINJAS.2020.36229.1003

(C) 2020 SINAI Journal of Applied Sciences. Published by Fac. Environ. Agric. Sci., Arish Univ. All rights reserved.
} 
2014). Psychrotrophic and/or mesophilic microorganisms were reported to be spread in meat processed foods including beef burger (Karpińska-Tymoszczyk, 2010).

Normal known and synthetic antibiotics was reported to fail in treating its targeted microorganisms because microorganisms developed resistance to it because of its extensive use which present a serious health hazard. That leads to the interest of finding antimicrobics alternatives preferably of natural sources such as medicinal and aromatic plants of a special importance to researchers, food producers and specially for consumer. The use of medicinal and aromatic plants with antimicrobial activity also possess a side benefit of containing some antioxidant active compounds that could inhibit lipid oxidation via being metal chelators, ultraviolet absorber, radical scavenger, singlet oxygen quenchers or oxygen scavenger. Making its application a primer contributor in food preservation (Abd El-Hamid et al., 2019; Lin et al., 2019). Medicinal and aromatic plants might be used as spices or food additives and its application in food might be due to its bioactive compounds which act as antimicrobial and antioxidant agents which would protect food of quality deterioration and spoilage in addition to their desired flavor and aroma. Nowadays, consumer's interest is gained by the application of biopreservatives from natural resources instead of chemical or synthetic ones because it is more safe and does not have side effects or toxicity (Moreira et al., 2005; Srinivasan, 2005; Chaul, 2015) .

Numerous investigations have reported that the application of medicinal and aromatic plants have their potential in preservation of food products of oxidation and microbial contamination. Marjoram (genus Origanum L., family: Lamiaceae) is one of the most beneficial plant used for decades by wide range of consumers as spice as well as a medicinal plant because of its pharmaceutical benefits. Marjoram was reported to contain high amounts of bioactive polyphenolic compounds that is very useful for health and have its therapeutic effects (El-Wakf et al., 2020). Marjoram was used in Egypt, Mediterranean countries as it is its native areas and it was also used world widely including Europe, Asia and North Africa for long time (Bellanca and Furia, 1971; Databases, 2010). The main compounds of marjoram were reported to include terpinen-4-ol (> $20 \%),(+)$-cis-sabinene hydrate $(3-18 \%), \alpha$ and $\gamma$-terpinene and terpinolene, thymol and carvacrol which let it possess its bioactivity (Almasi et al., 2020). Many other components were detected in Marjoram including phenolic terpenoids, flavonoids, phenolic glycosides, sisterol, triacontane which let it confer a strong antioxidant activity (Assaf et al., 1987; Novak et al., 2000; SkidmoreRoth, 2001; Minoura et al., 2003). Bioactivity of marjoram includes antioxidant, antimicrobial (antibacterial and antifungal), antiproliferative, hepatoprotective, antiinflammatory, antiulcer and cardioprotective activity which was correlated with its bioactive compounds in the extracts and in the essential oil (Kowalski et al., 2019). In the folkloric medicine marjoram was used for decades in the treatment of many illnesses including migraine, depression, cramps, paroxysmal coughs, dizziness, nervous headaches and gastrointestinal disorders (Demirel et al., 2015).

The current study aimed to evaluate the effect of adding marjoram (dried powder ethanolic extract) to beef burger each one with three concentrations through the investigation of cooking, physical, chemical, sensorial properties and microbial count during frozen storage at $-18{ }^{\circ} \mathrm{C}$.

\section{MATERIALS AND METHODS}

\section{Marjoram Powder and Extract}

Marjoram leaves were collected from North Sinai, Egypt. The plant was dried in 
forced air dryer oven (DHG-9140A; Yiheng Instrument Co., Ltd., Shanghai, China) at $40 \pm 1{ }^{\circ} \mathrm{C}$ until constant weight then it was grinded into powder using grinder (Moulinex, type LM 207, 500 Watt, France). Chemical composition of the powder including protein, fat and ash contents was assayed using the official method (AOAC, 2012). All chemical composition parameters including protein, fat and ash was expressed as percentages $(\%)$. Marjoram powder $(100 \mathrm{~g})$ was immersed in $1 \mathrm{~L}$ of ethanol $(95 \%)$ under vigorous shaking over $24 \mathrm{~h}$ under room temperature, mixture was filtered, then volume was reduced in a rotary evaporator (Heidolph, Laborata 4000-efficient, Germany), and residual extracting solvent was evaporated in oven, extract was then stored at $4^{\circ} \mathrm{C}$ until use in further experiments (Akbarmivehie and Baghaei, 2016)

\section{Beef Burger Preparation}

Beef burger was prepared according to the method described by the Egyptian standard specification for burger (ESS 1688/1991) (Kassem et al., 2011). Fresh cut beef was transported to the laboratory in an ice box, minced in an electric mincer (Moulinex, 2000 Watt, France) through a $4 \mathrm{~mm}$ plate. Minced meat $65 \mathrm{~g} / 100 \mathrm{~g}$, fat 20 $\mathrm{g} / 100 \mathrm{~g}$, soybean $5 \mathrm{~g} / 100 \mathrm{~g}$, black pepper 0.3 $\mathrm{g} / 100 \mathrm{~g}$, salt $1.8 \mathrm{~g} / 100 \mathrm{~g}$ and water 10 $\mathrm{g} / 100 \mathrm{~g}$ were thoroughly mixed for five minutes in the mixer using a spiral dough hook at medium speed (80rpm) and passed through smaller wholes plate to ensure homogeneity of the components. Prepared mix was divided into 7 portions; first one without any additives was labeled as control, three portions with the addition of marjoram ethanolic extract at $(0.1,0.2,0.3)$ $\mathrm{g} / 100 \mathrm{~g}$ and three portions with the addition of marjoram dry powder at $(0.2,0.4,0.6)$ $\mathrm{g} / 100 \mathrm{~g}$. Obtained pastes were shaped into approximately $50 \mathrm{~g}$ cylindric beef burger commercial forming tool $(10 \mathrm{~cm}$ internal diameter). Prepared beef burger was tightly covered with plastic films to prevent moisture loss and it was then stored in a foam plates at $-18{ }^{\circ} \mathrm{C}$. At zero time, first, second and third month of storage, samples of beef burger samples were taken to be evaluated for cooking, physical, chemical, sensorial properties and microbial count.

\section{Evaluation of Cooking Properties}

An electric grill (Arcelik Mini Firin, Turkey) was used to cook the prepared beef burger samples at $300^{\circ} \mathrm{C}$ for 6 minutes on a side and 4 minutes on the other with a total 10 minutes of cooking. Then, shrinkage, cooking loss, cooking yield were expressed as percentages (\%) according to next formulas:

\section{Shrinkage $\%=$ \\ $\frac{\text { Initial diameter }- \text { after cooking diameter }}{\text { Initial diameter }} \times$ \\ 100 \\ (El-Akary, 1986) \\ Cooking loss $\%=$ \\ Weight before cooking-Weight after cooking $X$ \\ 100 Weight before cooking}

(Crehan et al., 2000)

Cooking yield $\%=$

$\frac{\text { Cooked burger weight }}{\text { Uncooked burger weight }} \times 100$

(Murphy et al., 1975).

\section{Proximate Analysis of Burger}

Proximate analysis of beef burger samples was performed following the official method (AOAC, 2010). Moisture contents was measured as gram water per 100 gram sample was measured through the drying of three grams of sample in an forced air oven (DHG-9140A; Yiheng Instrument Co., Ltd., Shanghai, China) at $100^{\circ} \mathrm{C}$ until weight is constant. Ash contents (g ash/100 g sample) was analyzed by ashing in a muffle (Vulcan, D-Serious, Burnout Furnaces, Digital control) at $500^{\circ} \mathrm{C}$ for 5 hrs. protein contents (g protein/100 g 
sample) was performed by using a kjeldahl apparatus (Gerhardt, Type TT M, 1500 Watt, Germany) and for the conversion of nitrogen to crude protein a factor of 6.25 was used. Soxhlet apparatus was used to determine fat contents in samples measured as (g fat/100 g sample), sample was weighted after passing 6-cycles of excessive extraction in petroleum ether. All chemical composition parameters including moisture, ash, protein and fat was expressed as percentages $(\%)$.

\section{Physicochemical Properties of Beef Burger}

Water holding capacity (WHC) was measured using the method of El-Seesy (2000) as follows: minced meat burger sample $0.3 \mathrm{~g}$ was placed on an ashless filter paper Whatman, No. 41 and placed between two glass plates, and pressed for 10 minutes by one $\mathrm{kg}$ weight, two zones were found on the filter paper, their surface areas were measured by a planimeter. WHC was expressed as percentage (\%) using the following equation:

WHC $\%=\frac{\text { The inner area }\left(\mathrm{mm}^{2}\right)}{\text { The outer area }\left(\mathrm{mm}^{2}\right)} \times 100$

$\mathrm{pH}$ values of the prepared burger samples was determined by homogenizing $10 \mathrm{~g}$ of sample with $90 \mathrm{ml}$ of distilled water representing 1:9 (meat : water) ration for 1 minute, then $\mathrm{pH}$ value of the slurry is measured (Elgadir et al., 2015).

TBARS number was assessed in triplicates by the TBA method of Abdulla et al. (2016). Briefly, ten grams of beef burger sample was well homogenized with $25 \mathrm{ml}$ of distilled water for 2 minutes, mixed with $25 \mathrm{ml}$ of $10 \%$ trichloroacetic acid (TCA). Sample was filtrated (through Whatman filter paper No. 1), one $\mathrm{ml}$ of thiobarbituric acid $(0.06 \mathrm{M})$ in $90 \%$ acetic acid (TBA reagent) was added to $4 \mathrm{ml}$ of the filtrate in vial and mixed well. Vials were capped and heated in a boiling water bath for $10 \mathrm{~min}$ to develop the chromogen, cooled to room temperature. Absorbance at $538 \mathrm{~nm}$ was recorded, against a blank prepared with $4 \mathrm{ml}$ distilled water and $1 \mathrm{ml}$ TBA-reagent, using a spectrophotometer. The TBA numbers were calculated as $\mathrm{mg}$ malondialdehyde/kg sample according to the following equation:

TBARS number $(\mathrm{kg})=$ Absorbance $\times 7.8$

Total volatile nitrogen (TVN) was determined according to the method described by (Malle and Poumeyrol, 1989). In a blender, a mix formed of 100 grams of the beef burger sample, $200 \mathrm{~mL}$ of trichloroacetic acid (TCA) $(7.5 \%)$, the mix was passes through a filter paper. 25 of the filterate was applied to macro-kjeldahl apparatus distillation unit, spiked with $5 \mathrm{~mL}$ $\mathrm{NaOH}(10 \%)$ and distillate was received in $15 \mathrm{~mL}$ of boric acid (4\%), then titrated by $\mathrm{H}_{2} \mathrm{SO}_{4}(0.05 \mathrm{~N})$ and the end point was known using methylene red - bromocresol green. A $25 \mathrm{~mL}$ of trichloroacetic acid $(7.5 \%)$ instead of the sample was used as blank. TVN was calculated as $\mathrm{mg} / 100 \mathrm{~g}$ using the following equation:

$$
\begin{aligned}
& \text { T.V.N. (mg N/100gm) } \\
& =\frac{\mathrm{ml} \mathrm{of} 0.05 \mathrm{H}_{2} \mathrm{SO}_{4} \times 14 \times\left(200+\frac{\text { Moisture content }}{100-100}\right)}{25 \times 100}
\end{aligned}
$$

\section{Total Microbial Count in the Prepared Beef Burger}

Microbiological contamination and growth in the prepared beef burger was analysed using the total plate count (TPC) following the method described by (Abdulla et al., 2016). Briefly, during the storage period at zero time and at 1,2 and 3 months, $10 \mathrm{~g}$ of the beef burger samples were taken blended thoroughly with $90 \mathrm{ml}$ of sterilized peptone water using a lab dancer. A serial dilutions were made and $100 \mu$ of each dilution were transferred on a prepared plate count agar (Difco Laboratories, Detroit, MI, USA). After incubation for 48 hours at $35^{\circ} \mathrm{C}$, number of colonies were count and reported as $\log ^{10} \mathrm{CFU} / \mathrm{g}$ (Abdulla et al., 2016). 


\section{Sensory Evaluation Experiment}

Sensory evaluation test of the prepared beef burger samples were performed at zero time only. Beef burger samples were evaluated for sensory parameters including colour, taste, aroma, texture and over all acceptability (OAA) on a five points hedonic scale as 1 is dislike extremely and 5 like extremely (Lilic et al., 2015).

\section{Fatty Acids Profile}

Fatty acid of the sample was determined by GC methods as described in AOAC (2012). Accordingly, e $1.0 \mathrm{~g}$ of the extracted fat of the burger was put into a Teflon test tubes, spiked with $10 \mathrm{ml}$ of methanolic potassium hydroxide $(0.5 \mathrm{~N})$, refluxed for 90 minutes which was enough to get fat globules into solution then cooled down to room temperature. Fatty acids were liberated through adding sulphuric acid $(2 \mathrm{~N})$, then esterificated in the presence of $10 \mathrm{~mL}$ of catalytic methanol under boiling conditions for 20minutes followed by a direct cooling then extraction with hexane. Hexane layers was separated and washed using water and dried over anhydrous sodium sulphate.

Obtained methyl esters of fatty acid were then applied to a GC system (Perkin elemyre 8410 series with flame ionization detector) equipped with 2 meters column packed with celite coated with $10 \%$ DEGS. Operation conditions were; column temperature $140^{\circ} \mathrm{C}$, FID temperature $270^{\circ} \mathrm{C}$, injector temperature $260^{\circ} \mathrm{C}$ and carrier gas nitrogen with flow rate of $40 \mathrm{ml} / \mathrm{min}$. fatty acids were determined as percentages.

\section{Statistical Analyses}

The statistical analysis was carried out using one-way analysis of variance (ANOVA) under significant level of 0.05 for the whole results using Duncan's test was applied the statistical program Costate
(Ver. 6.400). To ascertain the significant among means of different samples.

\section{RESULTS AND DISCUSSION}

\section{Effects of Marjoram Addition and Storage on Chemical Composition of Burger}

\section{Chemical composition of marjoram powder}

Chemical composition of marjoram powder was assayed to evaluate it and to be linked to its effects on beef burger. Marjoram powder contained $77.4 \%$ moisture and the dry matter contained $12.01 \%$ ash, $22 \%$ of fibers, $17.19 \%$ fat and $10.06 \%$ protein.

Marjoram possessed a good antioxidant activity when checked for its total phenolic compounds (TPC) as it contained $13.97 \mathrm{mg}$ gallic acid equivalent/g, flavonoids contents was found to be $8.58 \mathrm{mg}$ quercetin equivalent $(\mathrm{QE}) / \mathrm{g}$ and that was in line with Bunghez et al. (2015) who reported that marjoram powder contained $9.26-22.77 \mathrm{mg}$ gallic acid equivalent/g and around 7.05$8.53 \mathrm{mg}$ quercetin equivalent (QE)/g (Bunghez et al., 2015). Marjoram showed a DPPH scavenging activity percentage of $92.43 \%$ which comes within the ranges found by Dhull et al. (2016) who reported that, marjoram scavenged $84.87-91.89 \%$ of DPPH free radical Bunghez et al. (2015) showing that marjoram could act as a strong antioxidant agent in the prevention of the autooxidation.

\section{Moisture contents of burger}

In meat products moisture is a very critical quality parameter that affects its juiciness as less moisture indicates a less juicy meat product (Teye et al., 2014). Moisture contents of beef burger at zero time and after storage period for 3 months are presented in Table 1, while the moisture 
Table 1. Effects of marjoram ethanolic extract and powder on the chemical changes of beef burger at the zero time and after the storage for 3 months

\begin{tabular}{|c|c|c|c|c|c|c|c|c|c|}
\hline & \multicolumn{3}{|c|}{ Parameter|\% Moisture contents } & \multicolumn{2}{|c|}{$\%$ Protein contents } & \multicolumn{2}{|c|}{$\%$ Fat contents } & \multicolumn{2}{|c|}{ pH values } \\
\hline \multicolumn{2}{|l|}{ Treatment } & Zero time & month $^{\text {rd } 3}$ & Zero time & month $^{\text {rd } 3}$ & Zero time & month $^{\text {rd } 3}$ & Zero time & month $^{\text {rd } 3}$ \\
\hline \multicolumn{2}{|l|}{ Control } & $* * \mathrm{~d} 58.79$ & d 57.93 & $* * * b$ A 20.60 & b C 11.10 & a C 13.42 & a A 16.58 & c A 6.00 & B c 5.70 \\
\hline \multirow{3}{*}{$\begin{array}{c}\text { Ethanolic } \\
\text { extract }\end{array}$} & $* 0.1$ & c 59.20 & c 58.34 & ab A 21.44 & $\mathrm{~b} \mathrm{C} 11.28$ & c C 10.82 & b A 14.63 & bc A 6.10 & bc B 5.80 \\
\hline & 0.2 & bc 59.90 & bc 59.04 & ab A 23.06 & b C 11.74 & c B-a 12.41 & ab A 15.84 & ab A 6.20 & ab B 5.90 \\
\hline & 0.3 & b 60.14 & b 59.28 & ab A 23.38 & b C 11.80 & a B 13.41 & ab A 16.26 & ab A 6.20 & ab B 5.90 \\
\hline \multirow{3}{*}{ Dried powder } & 0.2 & ab 60.40 & ab 59.54 & ab A 23.04 & ab B 13.52 & bc B 11.09 & ab A 15.99 & ab A 6.20 & ab B 5.90 \\
\hline & 0.4 & ab 60.60 & ab 59.74 & a A 23.83 & ab C 13.62 & bc B 11.23 & ab A 16.09 & ab A 6.20 & a B 6.00 \\
\hline & 0.6 & a 61.28 & a 60.42 & a A 23.85 & a B 14.66 & ab B 12.69 & ab A 16.37 & a A 6.30 & a BC 6.00 \\
\hline
\end{tabular}

* Addition levels of marjoram ethanolic extract and powders are in $\mathrm{g} / 100 \mathrm{~g}$ of the beef burger dough, ** Means followed by the same small letters within same column represents no significant differences between different treatments while different small letters indicate significant differences between different treatments (Effects of treatments), ***Means followed by the same capital letters within same row represents no significant differences between different storing months while the means with different capital letters indicate significant differences between different storing months (Effects of storage period).

contents of burger through frozen storage period $\left(1^{\text {st }}\right.$ month and $2^{\text {nd }}$ month in addition to zero time and the $3^{\text {rd }}$ month) at $-18^{\circ} \mathrm{C}$ could be merged from (Fig. 1.A. in appendixes). Table 1 and Fig.1.A shows the differences between moisture contents in different burger formulas that some of it contained marjoram extract and the other contained marjoram powders and the other contained no additives and labelled as control samples. From the data presented in Table 1.

From Table 1 it could be merged that minimal moisture contents were scored by the control beef burger samples $(58.79 \%)$. A significant increase $(\mathrm{P}<0.05)$ in moisture contents was scored by the burger with an added marjoram both as extract or powder, with a maximal moisture contents scored by the burger sample with $0.6 \mathrm{~g} / 100 \mathrm{~g}$ of marjoram powder with a score of $61.28 \%$ with an increase of $4 \%$ comparing to control burger. Same trend of changes was also obtained after the storage period (at frozen conditions) between different burger formula and additives. On the other hand, storing the beef burger for three months decreased moisture contents but the decrease was not significant $(\mathrm{P}<0.05)$. Maximum moisture contents scored by the higher amount of marjoram powders $(0.6 \mathrm{~g} /$ $100 \mathrm{~g}$ ) might be because of the high dietary fibre in the powder $(22 \%)$ as could be seen in (section 4.1.), fibres could retain moisture more strongly and hold it within the food system. Same trends of effects were reported at the application of buckwheat (high dietary fibre additive) in cookies as it caused an increased moisture contents (Abdel-Samie et al., 2011).

\section{Protein contents of burger}

Animal proteins is the only known source of essential amino acids and the body could not form it which give meat protein its importance and biological value (Moawad, 1995). In Table 1 and Fig.1.B. in appendixes), protein contents of the prepared beef burger without any addition (control sample), with the addition of marjoram ethanolic extracts or with the addition of marjoram powder of different levels was presented. Protein contents in the used marjoram powder was high $(10.06 \%$ as seen in section 4.1.1.), that is why its addition to the beef burger as ethanolic extract or powder scored significantly ( $p<$ 0.05 ) higher protein contents comparing to control. Maximal protein percentage was $23.85 \%$ and it was scored by the beef burger sample with $0.6 \mathrm{~g} / 100 \mathrm{~g}$ marjoram powder addition, followed by sample with 
the addition of $0.3 \mathrm{~g} / 100 \mathrm{~g}$ ethanolic extract as it scored protein content of $23.38 \%$ and minimal protein contents was scored in the control sample as it scored $20.60 \%$.

A sharp decrease in protein contents was obtained after storage period (for 3 months) as it decreased to become 11.1, 11.8 and $14.66 \%$ in control. Highest marjoram ethanolic extract and highest marjoram powder added treatments respectively, which comes in line with the results of Abdel-Salam et al. (2014) who reported a decrease in protein contents of the frozen beef burger samples after storage for 60 days (Abdel-Salam et al., 2014).

The decrease in protein contents in the marjoram powder added burger was less comparing to the decrease happening in control sample and marjoram ethanolic extract added burgers $(38.53 \%$ vs 46.12 and $49.53 \%$ for marjoram powder, control and marjoram ethanolic extract respectively). Biological value of protein in the marjoram powder was higher comparing to that in the ethanolic extract and that may be due to the effects of extraction solvent and thermal processes in the rotary evaporator and in the evaporation of solvents residues in the oven, which might decrease its bioavailability.

\section{Fat contents of burger}

Fat contents in marjoram powder is lower than that of meat itself that is why its addition to burger recipe showed decreased fat content $11.09-12.69 \%$ comparing to $13.42 \%$ in control sample. While the gradual increase in ethanolic extract showed a lower fat content 10.82 and $12.42 \%$ in the 0.1 and $0.2 \mathrm{~g} / 100 \mathrm{~g}$ while the $0.3 \mathrm{~g} / 100 \mathrm{~g}$ addition level of ethanolic extract showed similar fat contents $(13.41 \%)$ as control $(13.42 \%)$, ethanol has the ability to dissolve more fat and that was the reason behind the increase in fat contents with the gradual increase (higher concentration of marjoram extract) in ethanolic extract containing burger to reach same fat contents to control
(Table.1.) and (Fig.1.C, in appendixes). Data in the table showed that, after storage for three months, fat contents increased significantly $(\mathrm{p}<0.05)$ and that might be due to the decreased protein and moisture contents which caused a relative increase of fat to the total weight. Same trends of changes was obtained by Abdel-Salam $\boldsymbol{e t}$ al. (2014) who reported an increase in fat contents from through storage period which was 2 months (Abdel-Salam et al., 2014). Higher increase rat in fat contents in the marjoram added samples might also be ascribed to the fat holding capacity of the marjoram dietary fiber which was in accordance to what was found by AlJuhaimi et al. (2020) who obtained an increased fat contents at the application of baobab seeds poder which is rich in fibers (Al-Juhaimi et al., 2020).

\section{pH values of burger}

One of the main quality parameters of meat and meat quality is $\mathrm{pH}$ values which gives an indication of acid and alkalinity and $\mathrm{pH}$ is linked to all other quality parameters including colour changes, water holding capacity, texture and of course shelf life (Abd-El-Qader, 2003). From the $\mathrm{pH}$ data presented in Table 1 it could be noticed that, the burger with added marjoram ethanolic extract and marjoram powder of different levels showed higher $\mathrm{pH}$ (6.1-6.3) comparing to control samples (pH 6.0). Storing burger for three months caused a decrease in $\mathrm{pH}$, the decrease within the first month and the second month was not significantly different comparing to control while the decrease was significant (p, 0.05) at the third month (appendixes (Fig.1.D). Decreased pH values of burger might be due to the conversion of muscle glycogen to lactic acid (Abou Arab and Abou Arab, 2004). $\mathrm{pH}$ results findings recommend the end of storing period at the second month because the change at the third month was significant $(\mathrm{p}<0.05)$ 
which could be reflected to other quality parameters.

\section{Effects of Marjoram Addition and Storage on Water Holding Capacity of Burger}

Water holding capacity is defined as the ability of meat and meat products to retain moisture and it is one of the most quality characteristics that decide the juiciness and quality of meat and meat products. Visual acceptability, weight loss, cooking characteristics and sensory traits depends on WHC of meat and meat products. WHC capacity mechanisms is centered in structures of proteins especially myofibrillar that bind and entrap water which is strongly altered by the decline in $\mathrm{pH}$, ionic strength and oxidation which affect the efficiency of myofibrillar protein to retain water (Warner, 2017). Eating quality, tenderness, juiciness, thawing drip and cooking loss in meat and meat products are associated with the decrease of WHC (Morsi, 1988). It was reported that fibers of plant sources is strongly associated with the WHC and water swelling activity (Zhang et al., 2020).

Table 2 presents the effects of the addition of marjoram ethanolic extract or dried powder to the burger formula and the effects of frozen storage (at $-18^{\circ} \mathrm{C}$ ) for three months on its WHC. At zero time, minimal WHC was noted in the control beef burger samples without the addition of marjoram extract or powder with a score of $64.43 \%$. Addition of marjoram ethanolic extract showed a significantly $(\mathrm{p}<0.05)$ higher WHC that was in the range of 65.89$67.34 \%$ which might be ascribed to the higher protein contents in these treatments. Further significant $(p<0.05)$ increase in WHC was noted at the dried powder added beef burger samples (66.74-70.01\%) which might be due to the synergistic effects of the higher protein contents and high fiber contents in the added dried powder (10.06 and $22.0 \%$ respectively as could be merged from section 4.1.1). maximal WHC was that of the $0.6 \mathrm{~g} / 100 \mathrm{~g}$ added marjoram powder with a score of 70.01 at an increasing percent of $8.8 \%$ comparing to that of the WHC of control beef burger. Average of WHC in beef burger samples (average of all samples within different storage periods "Average A- in Table 2) followed the same behavior as was noted in zero time which gave the indicator that after storage period and the normal decrease in WHC same trend of changes in WHC within different treatments was reported. Same trend of changes was noted by Abou Arab and Abou Arab (2004) who reported an increase in WHC at the application of cardamom to a sausage system and it decreased with storing (Abou Arab and Abou Arab, 2004).

Gradual decrease in the WHC was noted in all beef burger samples including control, marjoram ethanolic extract and marjoram powder added samples. After storage, control beef burger showed minimal WHC $(58.02 \%)$, ethanolic extract was higher than that (59.57-61.02\%) and marjoram powder containing beef burger samples showed higher WHC comparing to both with a range of (60.42-63.69\%). Maximal WHC was that of the $0.6 \mathrm{~g} / 100 \mathrm{~g}$ added marjoram powder with a score of $63.69 \%$. Indicating that addition of ethanolic extract and powder of marjoram could improve the tenderness and juiciness of burger through increasing the WHC. The decrease in WHC might be due to the sharp decrease in protein contents in all samples through the storage period and may also be ascribed by the decrease in $\mathrm{pH}$ values through storage period (Table1). Average B. also confirmed that a significant $(\mathrm{p}<0.05)$ decrease in WHC through storage was happening as it started at $67.14 \%$ decreasing to reach its minimum at a score of $60.82 \%$ with a decrease percentage of $9.4 \%$ of the initial WHC. The decrease in WHC was also found by Hegazy (2004) when sausage was stored at freezing temperature $\left(-18^{\circ} \mathrm{C}\right)$ for three months. 
Table 2. Effects of marjoram ethanolic extract and powder on water holding capacity of beef burger

\begin{tabular}{|c|c|c|c|c|c|c|}
\hline \multirow{2}{*}{\multicolumn{2}{|c|}{ ieter }} & \multicolumn{5}{|c|}{$\%$ ding capacityWater hol } \\
\hline & & Zero time & month ${ }^{\text {st } 1}$ & month ${ }^{\text {nd }} 2$ & month ${ }^{\text {rd } 3}$ & $* * * *$ Average $\mathbf{A}$ \\
\hline & ntrol & $\mathrm{d}^{* *} \mathrm{~A} 64.34$ & $* * * \mathrm{~d}$ B 62.38 & d C 60.09 & d D 58.02 & $\mathrm{~d} 61.21$ \\
\hline $\begin{array}{c}\text { Ethanolic } \\
\text { extract }\end{array}$ & $\begin{array}{l}* 0.1 \\
0.2 \\
0.3\end{array}$ & $\begin{array}{c}\text { cd A } 65.89 \\
\text { c A } 66.75 \\
\text { bc A } 67.34\end{array}$ & $\begin{array}{c}\text { cd B } 63.93 \\
\text { c B } 64.79 \\
\text { bc B } 65.38\end{array}$ & $\begin{array}{c}\text { cd C } 61.64 \\
\text { c C } 62.50 \\
\text { bc C } 63.09\end{array}$ & $\begin{array}{c}\text { cd D } 59.57 \\
\text { c D } 60.43 \\
\text { bc D } 61.02\end{array}$ & $\begin{array}{c}\text { cd } 62.76 \\
\text { c } 63.62 \\
\text { bc } 64.21\end{array}$ \\
\hline Dried powder & $\begin{array}{l}0.2 \\
0.4 \\
0.6\end{array}$ & $\begin{array}{c}\text { c A } 66.74 \\
\text { ab A } 68.88 \\
\text { a A } 70.01\end{array}$ & $\begin{array}{c}\text { c B } 64.78 \\
\text { ab B } 66.92 \\
\text { a B } 68.05\end{array}$ & $\begin{array}{c}\text { c C } 62.49 \\
\text { ab C } 64.63 \\
\text { a C } 65.76\end{array}$ & $\begin{array}{c}\text { c D } 60.42 \\
\text { ab D } 62.56 \\
\text { a D } 63.69\end{array}$ & $\begin{array}{c}\text { c } 63.61 \\
\text { ab } 65.75 \\
\text { a } 66.88\end{array}$ \\
\hline$\underset{* * * * *}{\text { Average B }}$ & & A 67.14 & B 65.18 & C 62.89 & D 60.82 & \\
\hline
\end{tabular}

* Addition levels of marjoram ethanolic extract and powders are in $\mathrm{g} / 100 \mathrm{~g}$ of the beef burger dough, ** Means followed by the same small letters within same column represents no significant differences between different treatments while different small letters indicate significant differences between different treatments (Effects of treatments), ***Means followed by the same capital letters within same row represents no significant differences between different storing months while the means with different capital letters indicate significant differences between different storing months (Effects of storage period). Average A is the average of the whole treatment values, Average B is the average of the whole storage time values, **** Average $\mathrm{A}$ is the average of values of the whole treatment values within all storage months, $* * * * *$ Average $\mathrm{B}$ is the average of all values of different treatments within the same month.

\section{Effects of Marjoram Addition and Storage on Cooking Characteristics of Burger}

In meat products specially beef burger, cooking parameters are fundamental because it affects the consumers' acceptability through affecting quality and juiciness and furthermore, it affects nutritional value such as losing soluble vitamins and amino acids (Sayas-Barberá et al., 2020) Cooking characteristics of the prepared beef burger with the addition of both marjoram ethanolic extract and dried powder significantly $(\mathrm{p}<0.05)$ improved as could be seen in Table 3 and Fig. 2.A.-2.C..

Shrinkage after beef burger cooking measures the differences between the burger diameter before and after cooking and it reflects the amount of water and fat separated from the burger. It can be a clue on the quality of protein and on the ability of burger matrix to hold fat and water (Darwish et al., 2012). For consumers' thinking and believes, shrinkage of burger might be linked to the addition of water to the burger recipe which is un-preferred (El Zeny et al., 2019). From data in
Table.3. it could be cleared that, addition of the ethanolic extract of marjoram was able to decrease the shrinkage from its maximum value in control (24.29\%) gradually to reach $22.17 \%$ in the 0.3 marjoram ethanolic extract added to the burger. Further decrease in shrinkage was the result of the addition of marjoram dried powder gradually to reach minimal shrinkage score (20.25\%). Decreased shrinkage might be due to the higher protein contents, higher fiber contents and may also be attributed to the antioxidant activity of the additives (see section 4.1.1.) which all pour in the sake of improving water holding capacity and water retention in the burger system through cooking. Decreased protein contents, moisture contents and the fall of $\mathrm{pH}$ (Table 1) which might decrease the bioavailability of protein were all the reason behind decreasing in WHC (Table 2) and that was clearly reflected to an increased shrinkage scores through storage of beef burger samples. That was the same finding of Darwish $\boldsymbol{e t}$ al. (2012) who reported a decreased shrinkage when some medicinal plants was added to chicken burger and shrinkage also increased through storage period. 
Table 3. Effects of marjoram ethanolic extract and powder on the cooking characteristics of beef burger

\begin{tabular}{|c|c|c|c|c|c|c|c|}
\hline \multirow{2}{*}{$\begin{array}{c}\mathbf{P} \\
\text { Treatment }\end{array}$} & Parameter & \multicolumn{2}{|c|}{ \% Shrinkage } & \multicolumn{2}{|c|}{$\%$ Cooking loss } & \multicolumn{2}{|c|}{$\%$ Cooking yield } \\
\hline & & Zero time & month $^{\mathrm{rd}} 3$ & Zero time & month $^{\mathrm{rd}} 3$ & Zero time & month $^{\text {rd } 3}$ \\
\hline$\overline{\text { Control }}$ & & $\mathrm{a}^{* *} \mathrm{~A} 24.29$ & $* * *$ a B 26.89 & aA B 22.57 & a A 26.30 & c A 77.43 & с В 73.70 \\
\hline \multirow{4}{*}{$\begin{array}{c}\text { Ethanoli } \\
\text { extract }\end{array}$} & $* 0.1$ & ab A 23.01 & ab B 25.51 & ab B 21.11 & ab A 24.99 & bc A 78.89 & bc B 75.01 \\
\hline & 0.2 & c A-a 22.49 & c C-a 24.99 & ab C 20.78 & ab A 24.75 & bc A 79.22 & bc C 75.25 \\
\hline & 0.3 & c A-a 22.17 & c C-a 24.57 & bc C 20.00 & c A-a 23.97 & ab A 80.00 & c C-a 76.03 \\
\hline & 0.2 & ab A 22.65 & c C-a 25.05 & bc C 19.65 & bc A 23.62 & ab A 80.35 & ab C 76.38 \\
\hline Dried & 0.4 & bc A 20.63 & bc C 23.13 & bc C 18.91 & bc A 22.89 & ab A 81.09 & ab C 77.11 \\
\hline powder & 0.6 & c A 20.25 & c C 22.85 & c C 18.15 & c A 22.12 & a A 81.85 & a C 77.88 \\
\hline
\end{tabular}

* Addition levels of marjoram ethanolic extract and powders are in g/100g of the beef burger dough, ** Means followed by the same small letters within same column represents no significant differences between different treatments while different small letters indicate significant differences between different treatments (Effects of treatments), ***Means followed by the same capital letters within same row represents no significant differences between different storing months while the means with different capital letters indicate significant differences between different storing months (Effects of storage period).

Cooking loss of the marjoram added ethanolic extract or dried powder to the burger showed less cooking loss compared to control burger samples at zero time as well as after storing for three months. At zero time maximum cooking loss was obtained by control burger samples $(22.57 \%)$ while the addition of $0.3 \mathrm{~g} / 100 \mathrm{~g}$ of marjoram ethanolic extract decreased cooking loss at zero time to be $20.00 \%$. Further decrement to minimal cooking loss was obtained by the marjoram powder at $0.6 \mathrm{~g} / 100 \mathrm{~g}$ at a score of $18.15 \%$. Decreased cooking loss might be because of the higher fiber contents in the marjoram dried powder which could retain more water and the antioxidant activity in both marjoram ethanolic extract and dried powder. After storage period for three months, same trend of changes among treatments was obtained and all samples showed an increase in cooking loss, which may be due to the decreased protein, moisture contents and the decrease in WHC as a result. These findings comes in accordance to what was found by Darwish et al. (2012) who found that cooking loss decreased when thyme, rosemary marjoram and sage was added to chicken burger and author also reported an increased cooking loss after storage (Darwish et al., 2012).
A positive influence in cooking yield was obtained by the addition of marjoram ethanolic extract and marjoram powder as it increased from $77.43 \%$ in control sample to reach 80.00 and $81.85 \%$ in the 0.3 ethanolic extract and $0.6 \mathrm{~g} / 100 \mathrm{~g}$ marjoram dried powder added samples, respectively. The increase in cooking yield might be due to the existence of high amounts of fibre which is a hydrophilic constituents that adsorb water and form gels resulting in its retention in food system (Cócaro et al., 2020) in addition to the higher protein contents in the additives. After storage for three months decrease in protein, moisture and WHC caused a decrease in cooking yield with the same patterns of different samples (minimal cooking yield noted at control followed by the ethanolic extract added samples with a maximal score at the marjoram dried powder addition).

The proportional differences (increase in shrinkage, increase in cooking loss and the decrease in cooking yield) through the storage period (zero time, $1^{\text {st }}$ month, $2^{\text {nd }}$ month and the $3^{\text {rd }}$ month) could be seen in Fig. 2.A-2.C. In appendixes. While the data presented in Table 3. Presents only scores at the start of the storage (zero time) and at 
the end of the storage period (after three months).

\section{Effects of Marjoram Addition and Storage on TBA Values of Burger}

Lipid oxidation in food systems including meat products is the reason behind the formation of off-flavors and off-odors. TBA test gives a direct evaluation of lipid oxidation in meat products and the sensory evaluation is strongly related to it. TBA test is very sensitive to detect the unsaturated fatty acids decomposition which qualify it to determine oxidation more than peroxide values (Mohamed, 2005). Sayas-Barberá et al. (2020) reported that the addition of antioxidant active additives especially of plant with a high phenolic compounds relegate the rate of peroxidation and decrease TBA numbers as a result (Sayas-Barberá et al., 2020). According to the Egyptian Organization for Standardization and Quality (EOSQC)-(2005), TBA might not exceed $0.9 \mathrm{mg}$ malonaldehyde $/ \mathrm{kg}$ of meat products.

Influence of marjoram ethanolic extract and marjoram powder addition on the TBA values of the prepared beef burger samples and the TBA changes through frozen storage was presented in Table 4. At zero time, control beef burger sample was the maximal TBA $(0.42 \mathrm{mg}$ malonaldehyde $/ \mathrm{kg})$, while the addition of marjoram ethanolic extract showed lowered TBA value $(0.3 \mathrm{mg}$ malonaldehyde $/ \mathrm{kg}$ for the $0.3 \mathrm{~g} / 100 \mathrm{~g}$ marjoram ethanolic extract) but the change was not significant $(\mathrm{p}<0.05)$. Marjoram dried powder showed further significant $(\mathrm{p}$ $<0.05$ ) decreased TBA values to a minimal value for the $0.6 \mathrm{~g} / 100 \mathrm{~g}$ added powder at a score of $0.13 \mathrm{mg}$ malonaldehyde $/ \mathrm{kg}$. this trend of effects was always noted through the storage period as control was the highest values, followed by those of ethanolic extracts of marjoram while the beef burger with marjoram powder added was the minimal TBA scores through storage period. At the first month of storage, TBA values of all samples increased by a range of $3.0-25 \%$ of the initial TBA values, while in the second month the change reached an increase percentage of $6.6-55 \%$ of the initial values of TBA at the zero time. At the third month a huge change was noted in TBA values that reached duplication in some samples with a minimum change of $61.1 \%$ which indicated that after storing burger for 2 months the change was very fast in the oxidation of lipids. Lower changes was obtained in the added marjoram ethanolic extract and dried powder up to the second month which was due to the ability of the antioxidant active compounds to relegate the lipid oxidation but after the second month TBA dramatically increased even in the marjoram containing burgers, that is why we recommend ending the storing period at the second month. These findings was same to what was found by Darwish $\boldsymbol{e t}$ al. (2012) who found that, the spiking of chicken burger using rosemary, thyme and marjoram decreased the TBA and decreased the rate of its increase through storage (Darwish et al., 2012). Same findings and recommendation of stopping storage at 2 months period was noted by Sharaf $\boldsymbol{e t}$ al. (2009) because the TBA increased dramatically through storage.

Higher activity of the dried powder of marjoram comparing to its ethanolic extract in relegating the TBA increase might be because of the unsuitability of the extraction method to extract all antioxidant active compounds which make the powder more able to inhibit the lipid oxidation. That was also noted in dried holy basil powder which was more active in retarding oxidative rancidity and TBA values as well, comparing to its ethanolic extract (Juntachote et al., 2007).

\section{Effects of Marjoram Addition and Storage on TVN Values of Burger}

Degradation of protein in preserved meat products produces volatile nitrogen compounds, amines and hydrogen sulphide 
Table 4. Effects of marjoram ethanolic extract and powder on TBA and T.V.N through the storage period for three months

\begin{tabular}{|c|c|c|c|c|c|c|c|c|c|}
\hline \multirow{2}{*}{\multicolumn{2}{|c|}{$\overbrace{\text { Treatment }}^{\text {rParamete }}$}} & \multicolumn{4}{|c|}{ TBA values mg malonaldehyde/kg } & \multicolumn{4}{|c|}{ T.V.N mg/100g } \\
\hline & & Zero time & month ${ }^{\text {st }} 1$ & month ${ }^{\text {nd }} 2$ & month $^{\text {rd }} 3$ & Zero time & month ${ }^{\text {st } 1}$ & month ${ }^{\text {nd }} 2$ & month $^{\text {rd } 3}$ \\
\hline \multirow[t]{2}{*}{ Control } & & $\mathrm{a}^{* * \mathrm{C}} 0.42$ & a BC 0.50 & $* * * a B 0.56$ & a A 0.77 & a C 5.28 & a B 7.76 & a B 8.09 & a A 8.97 \\
\hline & $* 0.1$ & a B 0.36 & ab B 0.39 & b B 0.40 & b A 0.58 & $\mathrm{ab} C 4.77$ & ab B 7.20 & b AB 7.41 & b A 7.97 \\
\hline \multirow{3}{*}{$\begin{array}{c}\text { Ethanolic } \\
\text { extract }\end{array}$} & 0.2 & a B 0.33 & bc B 0.34 & b B 0.35 & b A 0.57 & b C 4.58 & b B 6.88 & bc $\mathrm{AB} 7.12$ & b A 7.65 \\
\hline & 0.3 & a B 0.30 & cd B 0.25 & b B 0.31 & b A 0.55 & b C 4.55 & b B 6.72 & cd B 6.77 & b A 7.47 \\
\hline & 0.2 & b B 0.16 & d B 0.17 & с B 0.18 & c A 0.32 & ab B 4.80 & c A 5.95 & d A 6.45 & c A 6.53 \\
\hline \multirow{2}{*}{$\begin{array}{l}\text { Dried } \\
\text { erpowd }\end{array}$} & 0.4 & b B 0.15 & d B 0.16 & $\mathrm{c} \mathrm{AB} 0.17$ & c A 0.30 & b B 4.61 & c A 5.92 & d A 6.38 & c A 6.43 \\
\hline & 0.6 & b B 0.13 & d B 0.14 & c B 0.16 & c A 0.29 & ab B 4.7 & c A 5.92 & d A 6.17 & c A 6.36 \\
\hline
\end{tabular}

* Addition levels of marjoram ethanolic extract and powders are in $\mathrm{g} / 100 \mathrm{~g}$ of the beef burger dough, ** Means followed by the same small letters within same column represents no significant differences between different treatments while different small letters indicate significant differences between different treatments (Effects of treatments), ***Means followed by the same capital letters within same row represents no significant differences between different storing months while the means with different capital letters indicate significant differences between different storing months (Effects of storage period).

which all cause a loss of the quality and bioavailability of proteins and of which ability to hold water decreases, nevertheless the loss of nutritional value because protein is the most important nutrient in meat products (Sharaf et al., 2009). The degradation of protein and nitrogenous substances to volatile nitrogen might also be caused by the microbiological activity that could increase TVN values through storage of meat products (Mahmoud, 2017). TVN of all samples increased significantly $(\mathrm{p}<0.05)$ during the frozen storage of beef burger but in different rates; reaching an increasing percentage of $69.89 \%$ at the third month comparing to its initial value for the control sample. Lower increasing percentages compared to the initial values were noted in the ethanolic extract spiked burger samples $(67.09,67.03$ and $64.18 \%$ for the $0.1,0.2$ and $0.3 \mathrm{~g} / 100 \mathrm{~g}$ of marjoram ethanolic extract respectively). Minimal changes rates (compared to the initial values) were obtained by the marjoram dried powder added beef burger samples at an increasing percentage of $36.04,39.48$ and $35.32 \%$ for the $0.2,0.4$ and $0.6 \mathrm{~g} / 100 \mathrm{~g}$ of marjoram dried powder respectively. Lowest $\mathrm{TVN}$ at the third month was obtained by the $0.6 \mathrm{~g} / 100 \mathrm{~g}$ marjoram dried powder added beef burger samples (at a TVN value of $6.36 \mathrm{mg} / 100 \mathrm{~g}$ ) while maximum TVN value was that of control $(8.97 \mathrm{mg} / 100 \mathrm{~g})$. None of the prepared beef burger samples exceeded the quality standards reported by the EOSQC (2005) as the maximum TVN value was 8.97 $\mathrm{mg} / 100 \mathrm{~g}$ (obtained by control at the third month time).

Lower TVN values through storage in the marjoram added beef burger samples might refer to its protective effects against microorganisms which fasten the degradation of protein to volatile nitrogen. That was in accordance with what was reported by Ozogul et al. (2013) when oregano, green tea and laurel extracts was added to a fish burger samples at frozen storage.

\section{Effects of Marjoram Addition and Storage on Total Plate Count of Burger}

Microbiological infections and growth in food systems cost a huge lost in food because it causes a serios of effects represents quality deterioration such as changing $\mathrm{pH}$ values, loss of protein and increasing TVN, secretion of toxins, and ends by the loose of food or might also 
cause food poisoning. Contamination and infections of microorganisms to the meat and meat products might be during slaughtering, processing, packaging, transportation or storage. Extensive use of synthetic and chemical antibiotics has led to resistant microorganisms which increased the preferability of natural alternative preservatives against microorganisms specially pathogenic ones (Lin et al., 2019). The use of Marjoram in this study was to inhibit the growth of microorganisms and that was measured through total bacterial count and the results was presented as $\log ^{10} \mathrm{CFU} / g$ (Table 5).

Average B showed that total plate count of all treatments increased significantly $(\mathrm{p}<$ 0.05 ) through storage period and Average B showed that control sample always showed higher total plate count compared to both marjoram ethanolic and marjoram powder added beef burger samples. Specifically, at zero-time, control sample showed maximal total plate count $\left(2.64 \log ^{10} \mathrm{CFU} / \mathrm{g}\right)$ while samples with the marjoram ethanolic extract showed significantly $(\mathrm{p}<0.05)$ lower total plate count at the range of (2.32$2.57 \mathrm{Log}^{10} \mathrm{CFU} / \mathrm{g}$ ) and further decrease of total plate count was those of marjoram powder containing beef burger samples as it showed 1.98-2.32 Log10 CFU/g with a minimal score $\left(1.98 \log ^{10} \mathrm{CFU} / \mathrm{g}\right)$ for the $0.6 \mathrm{~g} / 100 \mathrm{~g}$ marjoram powder added beef burger samples. Same differences were noted through all storage months as marjoram powder containing burger samples showed minimal total plate count and marjoram ethanolic extract added beef burger samples was higher than dried powder added samples but it maintained lower values comparing to control samples which always showed maximal values comparing to all beef burger samples in regards to total plate count. These results were the same found by Mohamed and Mansour (2012) when they applied marjoram essential oil to beef patties to control the total microbial count.

\section{Sensory Evaluation}

Of all parameters that could be analyzed, sensory analysis is the most useful test that reflect the real consumers' opinion about the product that has been prepared or developed especially in case of modified recipes (FAO, 2014). No significant differences were noted in the sensory parameters of the prepared beef burger including control samples, marjoram ethanolic extract or marjoram powder added beef burger samples. All tested parameters (color, taste, texture, aroma and the over-all acceptability) were significantly not different, which validate the application of marjoram ethanolic extract or marjoram powder in the preparation of beef burger. The insignificance in the sensory evaluation test might be because of two reasons, the first is the ethanolic extract and the powder of marjoram was added in minor ratios that could ne be observed by panelists and the second reason is that the marjoram is favored by some consumers which did not negatively altered the sensory parameters.

\section{Fatty Acid Profile of Frozen Stored Samples}

Unsaturated fatty acids is healthier that saturated fatty acids because it have the ability to reduces the blood arteriosclerosis and thrombotic tendency (Youssef $\boldsymbol{e t} \boldsymbol{a l}$., 2012). Data in Table 6 represents the concentrations of saturated and un-saturated fatty acids in control beef burger samples, $0.3 \mathrm{~g} / 100 \mathrm{~g}$ of marjoram ethanolic extract and $0.6 \mathrm{~g} / 100 \mathrm{~g}$ marjoram powder added beef burger samples. From the data in the table, it could be seen that, on one hand, saturated fatty acids in control samples $(49.87 \%)$ which was higher than that of the $0.3 \mathrm{~g} / 100 \mathrm{~g}$ marjoram ethanolic extract added samples which scored $46.18 \%$ while minimal saturated fatty acids concentration was obtained in the marjoram dried powder added burger samples. On the other hand, unsaturated fatty acids of control samples was minimal $(50.12 \%)$ and the $0.3 \mathrm{~g} / 100 \mathrm{~g}$ added marjoram ethanolic extract was higher $(53.81 \%)$ and maximal concentration was obtained by the marjoram powder added samples at a concentration of $66.79 \%$. 
Table 5. Effects of marjoram ethanolic extract and powder on Total plate count of beef burger during storage period

\begin{tabular}{|c|c|c|c|c|c|c|}
\hline \multirow{2}{*}{\multicolumn{2}{|c|}{$\mathrm{F}_{\text {Treatment }}$ Parameter }} & \multicolumn{5}{|c|}{ Total plate count $\log 10 \mathrm{CFU} / \mathrm{g}$} \\
\hline & & Zero time & month ${ }^{\text {st }} 1$ & month $^{\text {nd }} 2$ & month $^{\text {rd }} 3$ & $* * * *$ Average $\mathbf{A}$ \\
\hline \multirow[t]{2}{*}{ Control } & & $a^{* *} \mathrm{D} 2.64$ & $* * * \mathrm{aC} 3.01$ & a B 3.40 & a A 3.87 & a 3.23 \\
\hline & $* 0.1$ & ab D 2.57 & $\mathrm{ab} C 2.96$ & ab B 3.33 & ab A 3.80 & ab 3.17 \\
\hline \multirow{2}{*}{$\begin{array}{c}\text { Ethanolic } \\
\text { extract }\end{array}$} & 0.2 & bc D 2.41 & bc C 2.80 & bc B 3.20 & bc A 3.67 & bc 3.02 \\
\hline & 0.3 & c D 2.32 & c C 2.72 & $\operatorname{cd~B~} 3.11$ & $\operatorname{cd}$ A 3.58 & $\operatorname{cd} 2.93$ \\
\hline \multirow{3}{*}{ Dried powder } & 0.2 & c D 2.32 & c C 2.70 & cd B 3.07 & $\operatorname{cd}$ A 3.54 & $\operatorname{cd} 2.91$ \\
\hline & 0.4 & c D 2.24 & c C 2.62 & d B 2.99 & d A 3.46 & d 2.83 \\
\hline & 0.6 & d D 1.98 & d C 2.36 & e B 2.74 & e A 3.21 & e 2.57 \\
\hline \multicolumn{2}{|l|}{$* * * * *$ Average $\mathbf{B}$} & D 2.35 & C 2.74 & B 3.12 & A 3.59 & \\
\hline
\end{tabular}

Table 6. Effects of marjoram ethanolic extract and powder on sensory evaluation parameters; color, taste, texture, aroma, and over-all acceptability of beef burger

\begin{tabular}{|c|c|c|c|c|c|c|}
\hline \multirow{2}{*}{\multicolumn{2}{|c|}{$\mathrm{C}_{\text {Treatment }}$ Parameter }} & \multicolumn{5}{|c|}{ Sensory evaluation parameters } \\
\hline & & Color & Taste & Texture & Aroma & $* * \mathbf{O A A}$ \\
\hline \multirow[t]{2}{*}{ Control } & & 4.60 & 4.20 & 4.00 & 3.80 & 4.60 \\
\hline & $* 0.1$ & 4.40 & 4.20 & 3.60 & 4.20 & 4.00 \\
\hline \multirow{3}{*}{$\begin{array}{l}\text { Ethanolic } \\
\text { extract }\end{array}$} & 0.2 & 4.20 & 4.20 & 3.60 & 4.40 & 4.00 \\
\hline & 0.3 & 3.80 & 3.60 & 3.80 & 4.40 & 4.20 \\
\hline & 0.2 & 4.40 & 4.60 & 4.40 & 4.00 & 4.40 \\
\hline \multirow{2}{*}{$\begin{array}{c}\text { Dried } \\
\text { powder }\end{array}$} & 0.4 & 4.40 & 4.40 & 4.40 & 4.00 & 4.40 \\
\hline & 0.6 & 4.60 & 4.20 & 4.60 & 4.20 & 4.60 \\
\hline
\end{tabular}

* Addition levels of marjoram ethanolic extract and powders are in $\mathrm{g} / 100 \mathrm{~g}$ of the beef burger dough, ** OAA is over-all acceptability

\section{CONCLUSION}

Marjoram is a high antioxidant and high antimicrobial plant that was used in folk medicine for decades in many uses. Marjoram was added in two different forms; ethanolic extract (at 0.1, 0.2 and 0.3 $\mathrm{g} / 100 \mathrm{~g})$, and dried powder $(0.2,0.4$ and 0.6 $\mathrm{g} / 100 \mathrm{~g})$. Addition of marjoram was able to increase moisture contents, protein contents, water holding capacity and unsaturated fatty acids of beef burger while it caused a decrease in fat contents, TBA and TVN values. Cooking parameters were improved, microbiological growth was limited and sensory evaluation was not affected by the additives. Findings of this study suggests the application of marjoram in beef burger as ethanolic extract or dried 
powder because it improved its quality and sensory parameters. In regard to shelf life, marjoram was able to hold on good quality attributes till the second month, but the changes in $\mathrm{pH}$, TBA was fast after the second month, that is why we suggest to limit the storage of beef burger to two months although quality maintained good averages at the third month.

\section{REFERENCES}

AOAC (2012). Official Method of Analysis Association of Analytical Chemists. 19th Edition, Washington DC, 121-130.

Abd El-Hamid, M.I.; El-Sayed, M.; Ali, A.R.; Abdallah, H.; Arnaout, M.I. and El-Mowalid, G.A. (2019). Marjoram extract down-regulates the expression of Pasteurella multocida adhesion, colonization and toxin genes: A potential mechanism for its antimicrobial activity. Comparative Immunol., Microbiol. Infectious Dis., 62: 101-108.

Abd-El-Qader, M. (2003). Quality improvement of chicken frozen burger formulated with some spices or their volatile oils. M. Sc. Thesis, Food Sci. and Technol. Dept., Fac. Agric., Cairo Univ., Egypt.

Abdel-Salam, A.; El-Ghandour, $\mathbf{H}$. and Hassan, E.A. (2014). Antioxidant activity of thyme and sage and their antimicrobial impact against Listeria monocytogenes AND Pseudomonas putida in Beef Burger. J. Food Dairy Sci., 5(1): 15-31.

Abdel-Samie, M.A.S.; Huang, W.N.; Li, Z.N.; Yao, Y. and Chung, O.K. (2011). Acrylamide inhibition in cookies using natural antioxidants. 食品科学, 32.(07)

Abdulla, G.; Abdel-Samie, M. and D. Zaki, D. (2016)Evaluation of the antioxidant and antimicrobial effects of Ziziphus leaves extract in sausage during cold storage. J Pak. J. Food .20-Sci, 26, 10

.(Abou Arab, A.E. Abou Arab. (2004 Influence of rosemary and sage xtracts on deboned chicken meate quality. Minufiya J. Agric. Res, .180-169، (29)1

.(Akbarmivehie, M.H. Baghaei. (2016 The Effect of Addition Parsnip Herb and its Extract on Momtaze Hamburger Shelf Life. Eur. Online J. .146-Nat. Soc. Sci, 5(1), pp. 132

haimi, F., I. A. Babtain, I. a. M. Ju-Al Ahmed, O. N. Alsawmahi, K. Ghafoor, O. Q. Adiamo and E. E. Assessment of .(Babiker. (2020 oxidative stability and physicochemical, microbiological, and sensory properties of beef patties formulated with baobab seed onia digitata) extract. J Meat Adans) .Science, 162, 108044

Almasi, H., S. Azizi and S. Amjadi. Development and .(2020) characterization of pectin films activated by nanoemulsion and Pickering emulsion stabilized marjoram (Origanum majorana L.) ood Hydrocolloids, essential oil. J F .105338،99

Assaf, M., A. Ali, M. Makboul, J. Beck and R. J. P. M. Anton. Preliminary study of (1987) phenolic glycosides from Origanum majorana, quantitative estimation of arbutin; cytotoxic activity of 
،(4hydroquinone Planta Medica, 53(0 .345-343

.(Bellanca, N.T. E. Furia. (1971 Fenaroli's Handbook of Flavor .Ingredients. book. CRC Press

A. Rotar, R. M. Pop, -Bunghez, F., M. F. Romanciuc, F. Csernatoni, F. Fetea, Z. Diaconeasa and C. Comparative .(Socaciu. (2015 ESI+-LC phenolic fingerprint and MS composition of oregano-QTOF and rosemary hydrophilic extracts in relation to their antibacterial effect. Bull. UASVM Food Sci. Technol, .72

Characterization .(Chaul, L. T. (2015 and determination of antimicrobial ons of activity of extracts and fracti Rosmarinus officinalis Linn. rosemary), Origanym vulgare Linn. ) oregano) and Capiscum chinense) .Jacq. Goias Federal University

Chinprahast, N., A. Suwannadath, T. J. I. J. O. F. S. Homjabok and Use of .(Technology. (2012 nalis L.) rosemary (Rosmarinus offici leaf for improving oxidative stability precooked traditional -of microwave Thai pork patty and its frozen storage trial. Int. J. Food Sci. Technol, .2174-2165، (10)47

Cócaro, E. S., L. F. Laurindo, M. Alcantara, I. B. A. Martins, A. a. .(nd R. Deliza. (2020B. Junior a The addition of golden flaxseed flour Linum usitatissimum L.) in chicken ) burger: Effects on technological, sensory, and nutritional aspects. Food science Technology .112-international, 26(2), 105

Crehan, C., E. Hughes, D. Troy and Effects of fat .(Buckley. (2000 .D level and maltodextrin on the functional properties of frankfurters formulated with 5,12 and $30 \%$ fat. .469-Meat Sci, 55(4), 463

Geddawy, R. -Darwish, S. M., M. A. El M. Khalifa and R. A. Mohamed. anges of chemical ch-Physico (2012) frozen chicken burger formulated with some spices and herbs. Front. .199-Sci, 2, 192

Geddawy, R. -Darwish, S. M., M. A. El M. Khalifa, A. Rewaa and $R$. Antioxidant .(Mohamed. (2012 activities of some spices and herbs added to frozen chicken burger .152-Front. Sci, 2(6), 144

‘.-Databases, G. T. J. G. R. I. N. National Germplasm Resources Laboratory, Beltsville, Maryland. :Line At-Available on -Grin.Gov/Cgi-Http://Www. Ars .(PI. (2010 .Bin/Npgs/Html/Splist USDA, ARS, National genetic .997 .resources program

Demirel, S., F. Batıŏlu, E. Özmert .(and F. J. C. E. R. Erenler. (2015 The effect of multiple injections of ranibizumab on retinal nerve fiber -layer thickness in patients with age related macular degeneration. .92-Current Eye Research, 40(1), 87

ull, S. B., P. Kaur and S. S. Dh Phytochemical .(Purewal. (2016 analysis, phenolic compounds, condensed tannin content and antioxidant potential in Marwa Origanum majorana) seed extracts. ) -Effic. Technol, 2(4), 168-Resour. .174

Silva, Dos Santos Silva, R., L. P. Da A. Dos Santos Lima, F. L. N. De Oliveria and G. a. A. De Oliveira. 
Ação Antimicrobiana Dos .(2014) Óleos de Orégano e Alecrim em Combinação Ao Nitrito Frente À Staphylococcus Coagulase Positivo. .50-Blucher Food Sci Proc, 1(1), 49

\section{.(2005) .EGYPTIAN STANDARDS}

The Egyptian Organization for Standardization A.R.E. Frozen beef burger. Egyptian Standards. (No. (1991/1688

El Zeny, T., R. Y. Essa, B. A. Bisar .(and S. J. S. V. R. Metwalli. (2019 Effect of using chicory roots powder burger as a fat replacer on beef .514-quality. 56(Suppl. 22), 509

The technology .(Akary, M. (1986-EI and characteristics of beefburger containing plant substitutes Thesis, Fac of Agric., Alexandria Univ., .Egypt

Elgadir, M. A., M. S. Uddin, S. Ferdosh, A. Adam, A. J. K. and M. Z. I. Sarker. Chowdhury Impact of chitosan .(2015) composites and chitosan nanoparticle composites on various drug delivery systems: A review. J. Food Drug .629-Anal, 23(4), 619

Quality and safety .(Seesy, T. (2000-EI of meal burger patties using HACCP Paper presented at the .3 system Proceedings of the 3rd Conference of Food Industry at the Service of .Turisum, April

Habibi, -Wakf, A. M., E. S. M. El-El Ghany and R. -D. A. Ali, E. Abd El Marjoram and .(Elmougy. (2020 sage oils protect against testicular 67-apoptosis, suppressed Ki expression and cell cycle arrest as a therapy for male infertility in the of Food obese rats. Journal .Biochemistry, 44(1), e13080

Egyptian Organization .(EOSQC. (2005 for Standardization and Quality Control for chicken carcasses, No. .1090

IFAD (2012) The State .(Fao, W. (2014 of Food Insecurity in the World Economic growth is necessary :2012 not sufficient to accelerate but .reduction of hunger and malnutrition

the World Bank, the WTO, .(Fao. (2011 IFPRI and the UN HLTF. 2011. J Price volatility in food agricultural .markets

Lipids in .(Gandemer, G. $\mathbf{( 2 0 0 2}$ muscles and adipose tissues, changes ng processing and sensory duri properties of meat products. Meat .321-Sci, 62(3), 309

Aldapa, C. A., E. -Gómez De -Vargas, H. Bautista-Rangel .(Rosas. (2014-León and J. Castro O157 Shiga-Presence of non producing Escherichia coli, -toxin enterotoxigenic E. coli, nteropathogenic E. coli and e Salmonella in fresh beetroot (Beta vulgaris L.) juice from public markets in Mexico. Journal of the Science of Food Agriculture, Ecosystems \& Environment, 94(13), $.2711-2705$

-Hannon, J. C., J. P. Kerry, M. Cruz asim, M. H-Romero, S. Azlin .(Morris and E. Cummins. (2017 Kinetic desorption models for the release of nanosilver from an experimental nanosilver coating on polystyrene food packaging. Innovative food science emerging .158-technologies, 44, 149 
‘Chemical .(Hegazy, N. $\quad$ (2004 Micrbiological and Technological Studies on some Poultry Meat Products. M. Sci. Thesis, Food -Industry Dept., Fac of Agric., El .Mansoura Univ., Egypt

Juntachote, T., E. Berghofer, S. .(Siebenhandl and F. Bauer. (2007 Antioxidative effect of added dried $\mathrm{y}$ basil and its ethanolic extracts $\mathrm{Hol}$ on susceptibility of cooked ground pork to lipid oxidation. Food .135-Chemistry, 100(1), 129

Tymoszczyk, M. J. B. P. S. -Karpińska The effect of sage, sodium .(2010) erythorbate and a mixture of sage and sodium erythorbate on the quality of turkey meatballs stored under vacuum and modified atmosphere conditions. Br. Poult. .759-Sci, 51(6), 745

Alla and F. Ali. -em, G., O. AttaKass Improving the quality of beef .(2011) burger by adding thyme essential oil and jojoba oil. J Archivos de .795-zootecnia, 60(231), 787

Kowalski, R., G. Kowalska, U. Pankiewicz, A. Mazurek, M. Stasiak, M. Sujka and-Wlodarczyk The effect of .(J. Wyrostek. (2019 an addition of marjoram oil on stabilization fatty acids profile of .232-rapeseed oil. J LWT, 109, 225

Lilic, S., I. Brankovic, V. Koricanac, D. Vranic, L. Spalevic, M. Pavlovic .(and B. J. P. F. S. Lakicevic. (2015 cing sodium chloride content in Redu meat burgers by adding potassium .167-chloride and onion. 5, 164

Samie and H. -S. Abdel-Lin, L., M. a. Novel packaging .(Cui. (2019) .systems in food
Effect of .(Mahmoud, E. A. (2017 Rosemary, Basil, and Mint Leaves n Quality of Chilled Extracts o Chicken Burger. J. Food Dairy Sci, .161-151،(3)8

A new .(Malle, P.M. Poumeyrol. (1989 chemical criterion for the quality control of fish: trimethylamine/total volatile basic nitrogen (\%). Journal .423-of Food Protection, 52(6), 419

noura, D., R. Kawamura and Mi A mechanism of .(Matsuura. (2003 the onset of the South Asian summer monsoon. J. Meteorol. Soc. Jpn. Ser. .580 -II, 81(3), 563

Effect of .(Moawad, R. (1995 pretreatment on quality attributes and nutritive value of frozen beef and chicken meats. Ph. D. Thesis, Food Science and Technology Dept., Fac .of Agric., Cairo Univ., Egypt

Low Fat Meat .(Mohamed, H. (2005 Products as Prepared from Ostorich and other Reduced Fat Beef. Ph. D. Thesis, Nutrition and Food Science Economics Dept., Fac of Home

Mohamed, H. M., H. A. Mansour and The .(D. H. Farag. (2011-M. D. E. use of natural herbal extracts for improving the lipid stability and sensory characteristics of irradiated .39-ground beef. Meat Sci, 87(1), 33

Mohamed, H. M.H. A. Mansour. 20122).( Incorporating essential oils of marjoram and rosemary in the formulation of beef patties manufactured with mechanically deboned poultry meat to improve the lipid stability and sensory attributes. .87-Food Sci Techol, 45(1), 79-LWT

e, C. Del Valle Moreira, M., A. Ponc Inhibitory .(and S. Roura. (2005 
parameters of essential oils to reduce Food -a foodborne pathogen. LWT .570-Sci Techol, 38(5), 565

Studies on freezing .(Morsi, H. (1988 preservation of meat. Ph. D. Thesis, '.Food Science and Technology Dept .Fac of Agric., Cairo Univ., Egypt

Murphy, E. W., P. E. Criner and B. Comparisons of .(C. Gray. (1975 methods for calculating retentions of nutrients in cooked foods. J. Agric. .1157-Food Chem, 23(6), 1153

Novak, J., C. Bitsch, J. Langbehn, F. oula, Y. Gotsiou and Pank, M. Sk -Ratios of cis .(C. M. Franz. (2000 sabinene hydrate in -and trans Origanum majorana L. and Origanum microphyllum (Bentham) Vogel. Biochemical Systematics and .704-Ecology, 28(7), 697

Ozogul, Y., Y. J. F. Uçar and B. The effects of .(Technology. (2013 natural extracts on the quality changes of frozen chub mackerel Scomber japonicus) burgers. Food) -Bioprocess Technol, 6(6), 1550 .1560

-Barberá, E., A. M. Martín-Sayas Abda -Sánchez, S. Cherif, J. Ben .(Álvarez. (2020-and J. Á. Pérez date (Phoenix dactylifera Effect of L.) pits on the shelf life of beef .burgers. J Foods, 9(1), 102

Sharaf, A., M. Ebrahium, M. Ammar, Ghany -M. J. W. J. O. D. Abdel Influence of .(and F. Sciences. (2009 using moringa meal flour as meat istics of extender on quality character beef burger patties during frozen .40 -storage. $4(1), 32$
Mosby's .(Roth， L. (2001-Skidmore handbook of herbs \& natural supplements. book. Mosby St Louis` .eMO MO

Role of spices .(Srinivasan, K. (2005 beyond food flavoring: iple health Nutraceuticals with mult -effects. Food Rev. Int, 21(2), 167 .188

Teye, G. A., J. Bawah, F. Adzitey and Effect of .(L. N. Nathaniel. (2014 sweet basil (Ocimum basilicum) leaf extract as a spice in hamburger. book. World Science and Research .Publishing

ecker and J. M. Tian, F., E. A. D Controlling lipid .(Goddard. (2013 oxidation of food by active packaging technologies. J Food .680-function, 4(5), 669

The eating .(Warner, R. D. (2017 holding -IV water-quality of meat capacity and juiciness Lawrie' $\mathrm{s}$ :(459-Meat Science (pp. 419 .Elsevier

Youssef, M. K., B. M. Mostafa, M. A. .(Seliem and A. M. Hashem. (2012 Total Lipid Fractions and Fatty Fat Beef-Acids Composition of Low -Burger. Food Public Health, 2(2), 34 .39

Zhang, Y., J. Qi, W. Zeng, Y. Huang ties of Proper .(and X. Yang. (2020 dietary fiber from citrus obtained through alkaline hydrogen peroxide treatment and homogenization treatment. J Food chemistry, 311, .125873 . 


\section{Appendixes}

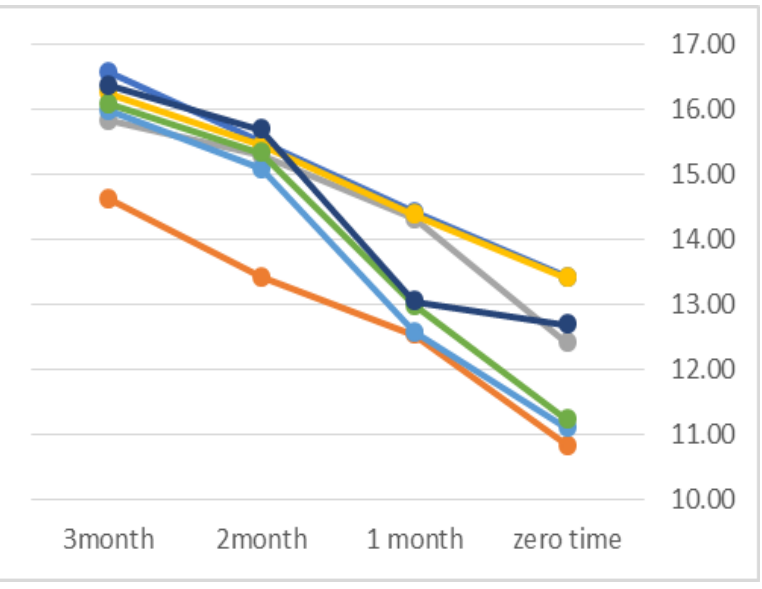

Fig.1. A. Moisture
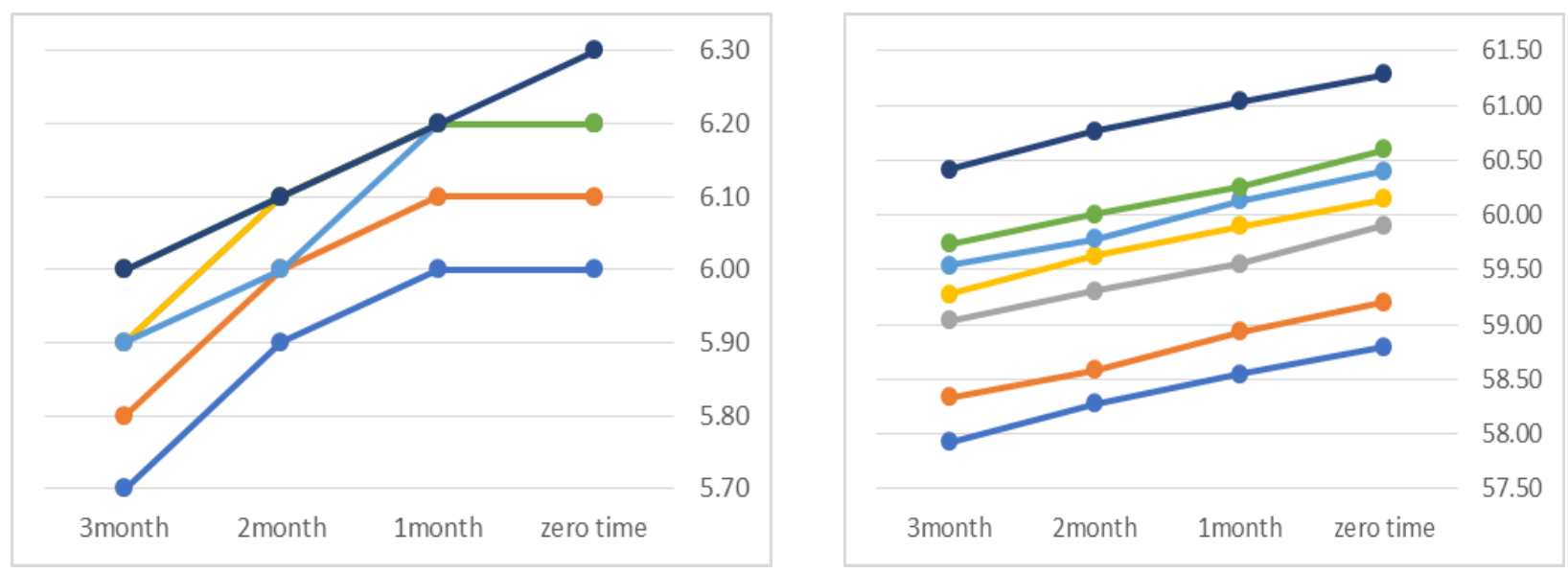

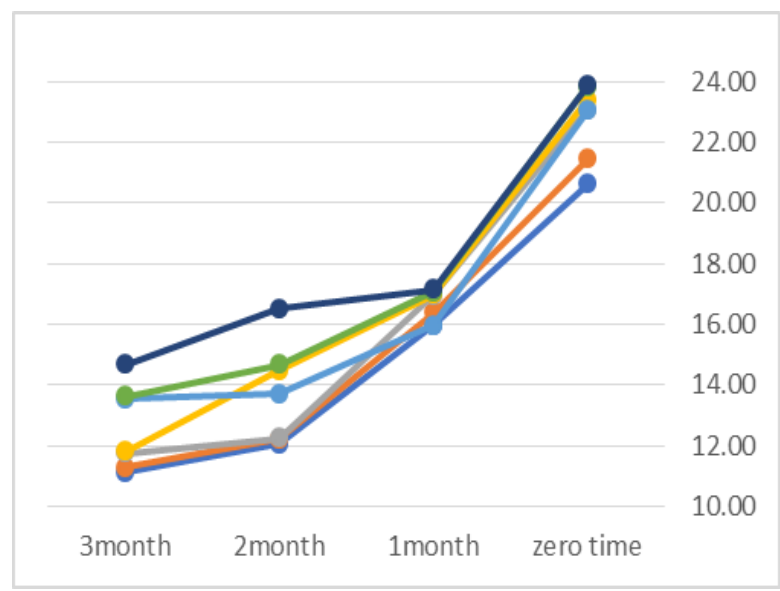

Fig.1. B. Protein

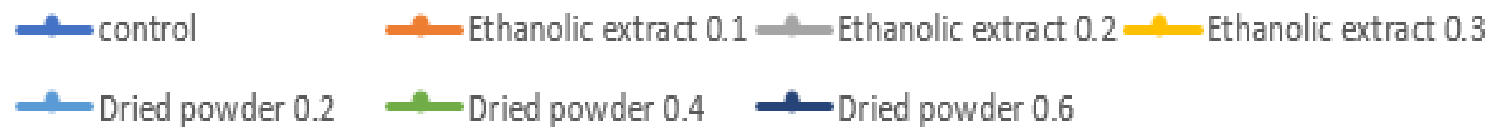

Fig.1. C. Fat

Fig.1. D. pH

Fig.1. A-C Effects of Marjoram addition and storage on moisture (1.A.), protein (1.B.), fat (1.C.) and pH (1.D.) of burger 
Ragab, et al. | SINAI Journal of Applied Sciences 9 (2) 2020 225-246

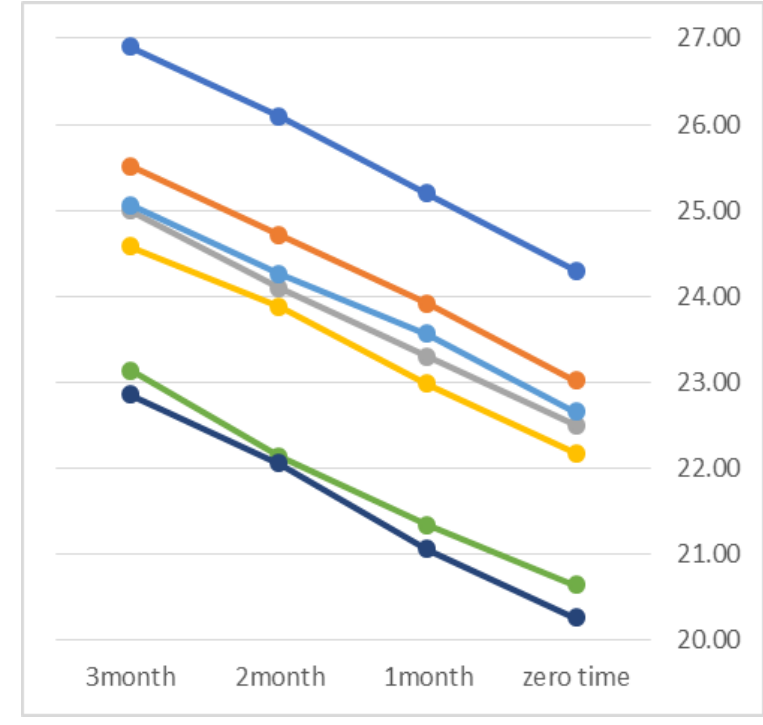

Fig.2. A. Shrinkage

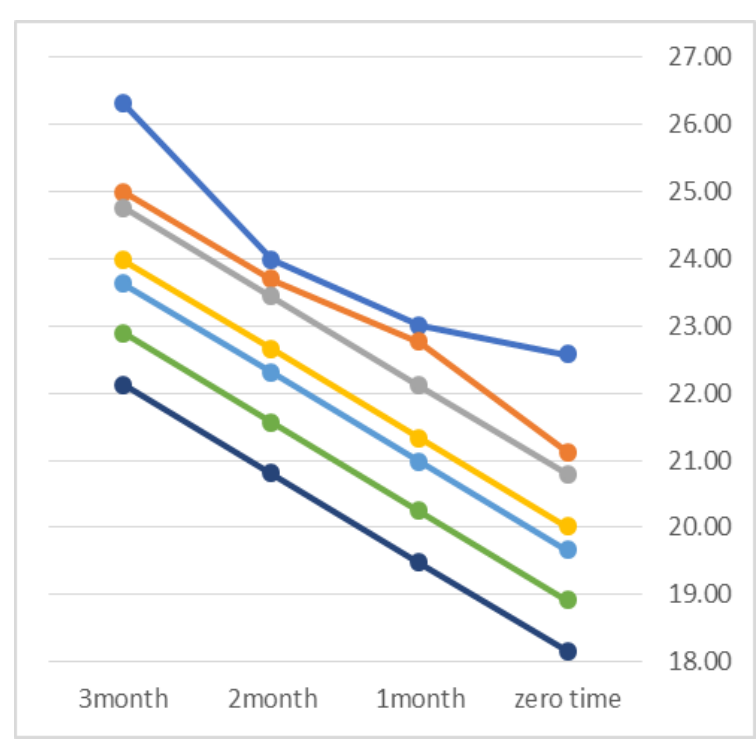

Fig.2 B. Cooking loss

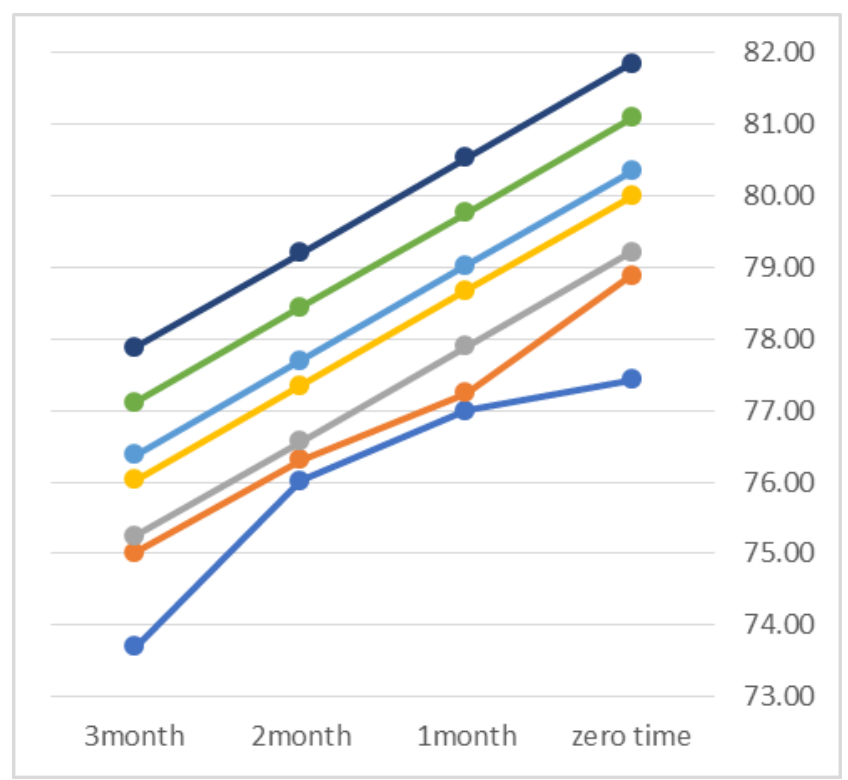

Fig.2. C. Cooking yield

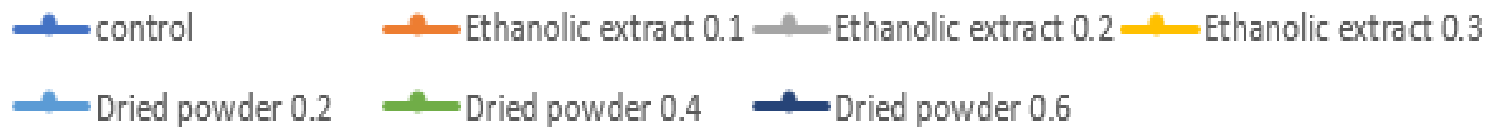

Fig.2.A.-C. Effects of Marjoram addition and storage on shrinkage (1.A.), cooking loss (1.B.) and cooking yield (1.C) of beef burger 


$$
\text { الملخص العربي }
$$

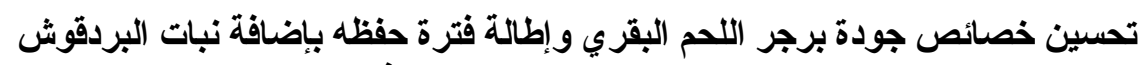

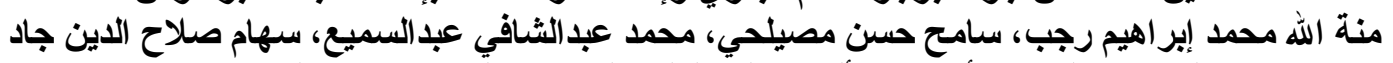

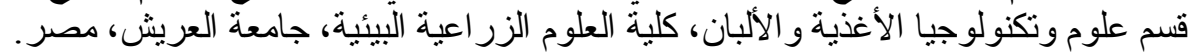

تم إضافة البردقوش إلى برجر اللحم البقري لتحسين خو اصه الفيزيائية و الكيميائية و إطالة فترة حفظه. تم إضافة البردقوش إلى برجر اللحم في صورثين للإضافة: كمستخلص إيثانولي بتركيز 0.1 و 0.2 و 0.3 جم/ عشبي جاف بتركيز 0.2 و0.4 و 0.6 جم/ 100 جم وتم تخزين برجر اللحم في درجة حرارة -18 لمدة ثناثنة أثنهر. تم

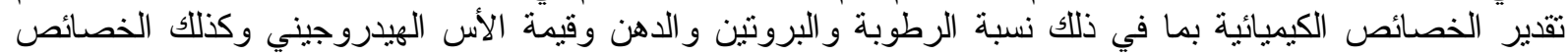

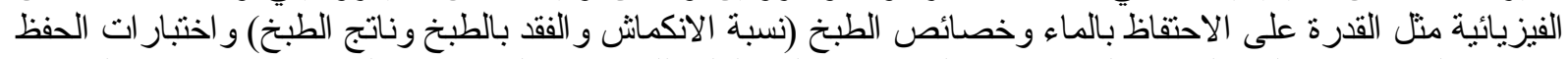

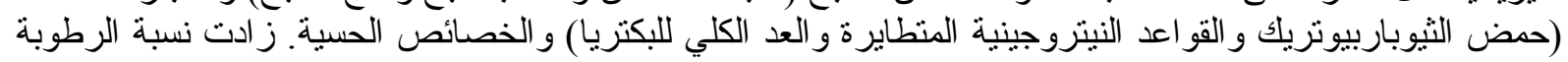

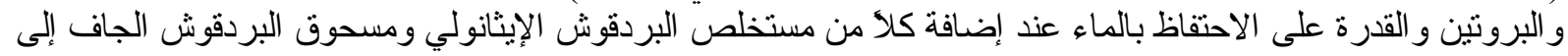

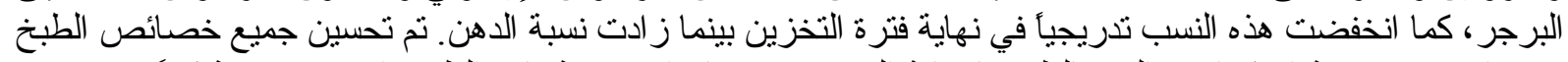

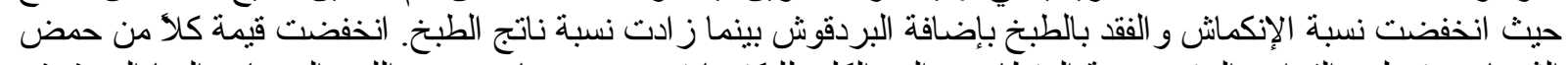

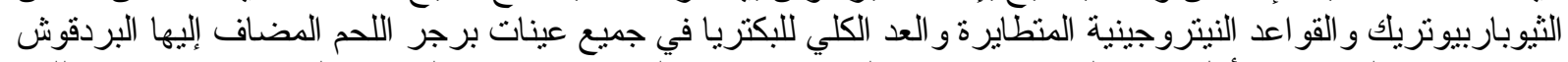

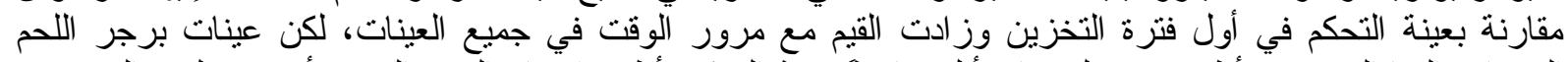

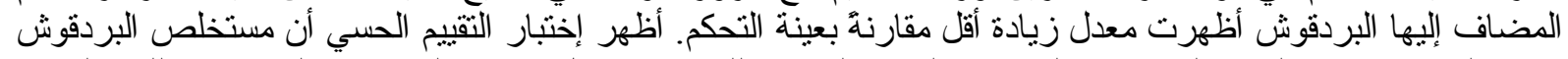

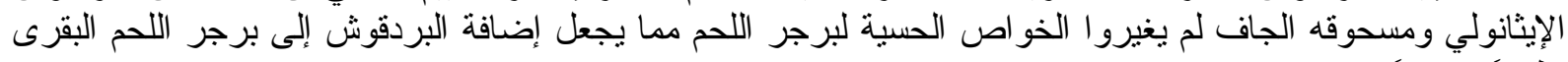
تطبيقاً محتملان. الكلمات الاسترشادية: البردقوش، برجر اللحم البقري، البدائل الطبيعية، المو اد الحافظة.

أستاذ علوم الأغذية، كلية التربية الجامعية، جامعة الطائف، المملكة العربية السعودية. أستاذ علوم الأغذية، كلية العلوم الأغذية و الهندسة الصيد لانية، جامعة جانة نور مال نانجيانغ، الصين.

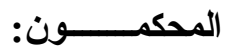

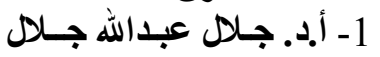
2- أ.د. فوزي ناصر النداري عيداله جي 